\title{
Evaluation of a commercial radioisotopic kit for folate assays
}

\author{
P. W. HILL AND D. W. DAWSON \\ From the Department of Haematology, North Manchester General Hospital, Manchester M8 6RB
}

SUMMARY A commercial kit for the radioisotopic assay of folate in serum, the Bio-Rad 'Quanta Count' folate kit, produced lower results than the Lactobacillus casei microbiological assay method. Its normal range was $2 \cdot 0-13 \cdot 0 \mu \mathrm{g} / 1$ and the reproducibility was similar to that of the microbiological assay method. The kit was also satisfactory for whole blood folate assays. The cost requires careful consideration before the kit is used for routine purposes.

For many years most laboratories have depended upon a microbiological technique for folate assays. Radioisotope methods using tritium or carbon-14 labels have been available, but their use has been limited by the expense of appropriate counting equipment. Recently, however, several commercial kits using radioiodinated labelled folate compounds, measurable in widely used gamma counters, have appeared, and we here report our experiences with one of them including comparison with a microbiological assay.

\section{Material and methods}

\section{RADIOISOTOPE TECHNIQUE}

'Quanta Count' folate kits were supplied by Bio-Rad Laboratories Ltd. The radio-ligand method is based on the principle of saturation analysis. Each kit contains iodine-125 (125I) labelled pteroyl glutamic acid (Pte-Glu) derivative, borate buffer $\mathrm{pH} 9 \cdot 6$, absorbent charcoal tablets, and $\beta$ lactoglobulin as binding agent. The six standards supplied consist of lyophilised folate-free human serum containing varying amounts of Pte-Glu, range $0-20 \mu \mathrm{g} / 1$ when reconstituted. The kits available are sufficient for testing 44 or 94 unknown samples in duplicate; $0 \cdot 1$ $\mathrm{ml}$ of sample is diluted in $1.0 \mathrm{ml}$ of isotope in borate buffer. The diluted samples are heated for 15 minutes in a boiling bath and cooled to room temperature; $1.0 \mathrm{ml}$ of binder is added and the samples are incubated at room temperature for 30 minutes. An absorbent tablet is added to each tube and, after vortex mixing, the tubes are centrifuged.

Received for publication 4 October 1976
The manufacturer's instructions are easy to follow, but it is found difficult with certain kits to decant the supernatant without disturbing the charcoal deposit which contains the unbound folate. Some charcoal also sticks to the sides of the tube during vortex mixing and is liable to be decanted. More reproducible counts are obtained by pipetting $1.5 \mathrm{ml}$ of the supernatant into the counting vial, and this procedure was followed throughout.

Samples were counted for one minute on a Beckman 'Biogamma' counting system, preset with a ${ }^{125}$ I cartridge. A 'blank' tube, the count deducted from all others except the 'total counts' tube, consists of a 1/10 dilution of the zero standard in isotope buffer processed in the same way as the other tubes but with no added binder. The 'total counts' tube, $1 \mathrm{ml}$ of diluted isotope, is also prepared. The counts are expressed as a percentage of the total counts, using the formula

$$
\frac{B}{T} \times 100
$$

where $B$ is test-blank cpm for each tube and $T$ is cpm of the total counts tube. The standard percentages are plotted on linear graph paper and the unknown samples are read from the graph.

\section{MICROBIOLOGICAL TECHNIQUE}

A chloramphenicol-resistant Lactobacillus casei (self adapted) is stored in liquid nitrogen. The organism, at an optical density at $530 \mathrm{~nm}$ of 0.2 , is stored in aliquots. One millilitre of suspension is added to each litre of medium. The medium used is ' $Q$ Ess', produced by Becton Dickinson and Company, to which chloramphenicol is added. $0.1 \mathrm{ml}$ of serum is 
diluted in $7.0 \mathrm{ml}$ of medium and incubated for 24 hours before being read colorimetrically. A standard graph is prepared and the unknown samples are read from it. The normal range for this method in our laboratory is $3-8 \mu \mathrm{g} / 1$, mean $5.4 \mu \mathrm{g} / 1$.

The sera tested were not stored with ascorbic acid because assays were carried out within eight days of collection; however, ascorbate treated sera were used in experiments to assess the effect of storage on the radioisotope kit and to determine differences between kits of different batches.

For whole blood assays by both methods the samples were diluted $1 / 20$ in ascorbic acid (Hoffbrand et al., 1966) and assayed as the sera above.

\section{Results}

The sera from 72 normal persons fell within the range $2 \cdot 0-13 \cdot 0 \mu \mathrm{g} / \mathrm{l}$, mean $4 \cdot 7 \mu \mathrm{g} / \mathrm{l}$, using the radioisotopic method. The results from 245 hospital patients are shown in Figure 1. Twenty-one results have been excluded from Fig. 1, 15 because the microbiological result was above the range covered by the technique and six because discrepancy between the results by the two methods was considered to be due to antibiotic therapy (see below).

RADIOISOTOPE KIT SHELF-LIFE

Eighteen ascorbate treated sera were tested when one kit was received and again with the same kit after

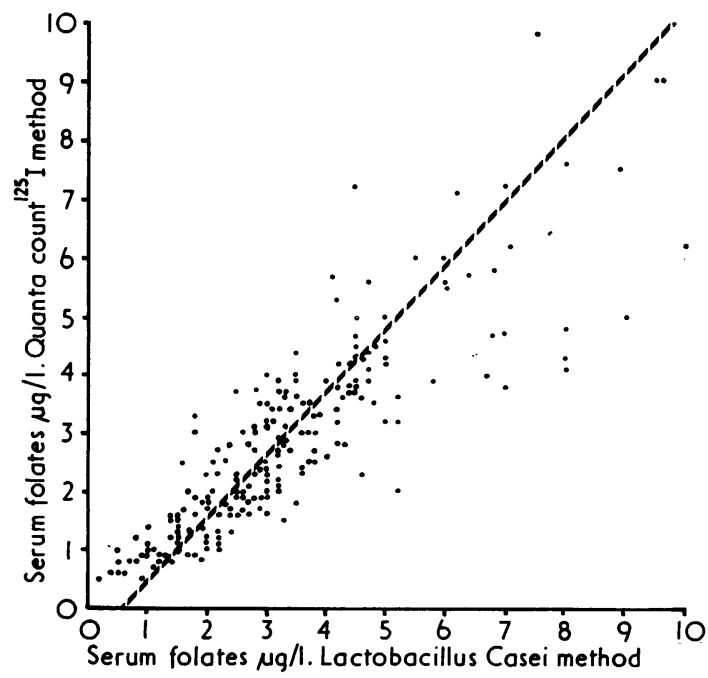

Fig. 1 Comparison of serum folate values obtained for 245 sera by the 'Quanta Count' and Lactobacillus casei methods

Regression line, $x=0.96 y+0.58$. refrigeration for five weeks, that is, at the end of the isotope's 'shelf' life. The same sera were also tested microbiologically (Table 1). The two sets of microbiological assay results were not different; eight were lower and 10 higher after storage of the sera. With the radioisotope techniques there was a greater fall in the mean value and 13 of the sera gave lower results with the stored kit; but the difference between the means was not significant.

BATCH-TO-BATCH VARIATION

Eighteen sera were tested at the same time using the two kits of different batch number (Table 2). The difference between the means was not significant.

\section{PRECISION}

Four sera were tested 20 times in the same assay (Table 3). The coefficients of variation of the normal sera were very satisfactory. The coefficient of $>$ variation for the microbiological technique was $5.9 \%$ for serum tested 20 times with a mean result of $4 \cdot 5 \mu \mathrm{g} / 1$.

\section{RECOVERY OF PTEROYLGLUTAMIC ACID}

When 5 and $10 \mu \mathrm{g} / 1$ Pte-Glu were added to eight sera the mean recovery was not as good as expected (Table 4).

\section{DILUTION}

Seven sera were tested neat (final dilution 1/21) and at two dilutions (Table 5). The results at both dilutions showed a decrease of at least $9 \%$.

Table 1 Comparison of serum folate concentrations, as measured by the radioassay and microbiological methods at the beginning and end of the 'Quanta Count' shelflife

\begin{tabular}{|c|c|c|c|c|}
\hline & \multicolumn{2}{|l|}{ L. casei } & \multicolumn{2}{|c|}{ 'Quanta Count' } \\
\hline & Week 1 & Week 5 & Week 1 & Week 5 \\
\hline & $\begin{array}{l}1.7 \\
47 \\
05 \\
3.4 \\
3.4 \\
3.0 \\
1.0 \\
4.3 \\
3.2 \\
3.2 \\
3.2 \\
4.5 \\
3.7 \\
5.0 \\
5.0 \\
7.0 \\
2.6 \\
2.1\end{array}$ & $\begin{array}{l}2.2 \\
5.2 \\
0.8 \\
3 \cdot 2 \\
3.9 \\
3 \cdot 5 \\
1 \cdot 1 \\
3.8 \\
2.4 \\
3 \cdot 0 \\
2.8 \\
4.4 \\
3.9 \\
4.6 \\
5 \cdot 2 \\
6.4 \\
2.7 \\
2.2\end{array}$ & $\begin{array}{l}1 \cdot 1 \\
4.7 \\
1 \cdot 1 \\
2.9 \\
3.8 \\
3.9 \\
0.6 \\
3.9 \\
2.9 \\
3.0 \\
2.8 \\
4.8 \\
4.4 \\
5.3 \\
4.5 \\
7.1 \\
1.9 \\
2.0\end{array}$ & $\begin{array}{l}1.0 \\
5.0 \\
0.8 \\
2.4 \\
3.3 \\
4.0 \\
0.7 \\
3.3 \\
1.6 \\
2.5 \\
2.8 \\
37 \\
3.6 \\
5.6 \\
3.6 \\
5.7 \\
1.1 \\
1.3\end{array}$ \\
\hline $\begin{array}{l}\text { Mean } \\
\text { SD }\end{array}$ & $\begin{array}{l}3.4 \\
1.6\end{array}$ & $\begin{array}{l}3 \cdot 4 \\
1 \cdot 5\end{array}$ & $\begin{array}{l}3.4 \\
1.7\end{array}$ & $\begin{array}{l}3.9 \\
1.6\end{array}$ \\
\hline
\end{tabular}


Table 2 Comparison of two 'Quanta Count' kits showing batch-to-batch variation

\begin{tabular}{lll}
\hline & Kit 1 & Kit 2 \\
\hline 1.1 & 1.3 \\
& 4.7 & 4.4 \\
1.1 & 1.0 \\
2.9 & 2.7 \\
& 3.8 & 3.4 \\
& 3.9 & 4.0 \\
0.6 & 1.0 \\
& 3.9 & 3.6 \\
& 2.9 & 2.1 \\
& 3.0 & 2.2 \\
& 2.8 & 2.7 \\
& 4.8 & 4.3 \\
& 4.4 & 3.5 \\
& 5.3 & 5.0 \\
& 4.5 & 4.6 \\
Mean & 7.4 & 6.6 \\
SD & 1.9 & 1.9 \\
\hline
\end{tabular}

Table 3 Precision of tests on four sern

\begin{tabular}{|c|c|c|c|c|}
\hline & Serur & & & \\
\hline & 1 & 2 & 3 & 4 \\
\hline & $1 \cdot 1$ & $2 \cdot 6$ & $6 \cdot 8$ & 12.6 \\
\hline & 0.8 & $2 \cdot 6$ & $6 \cdot 6$ & $10 \cdot 8$ \\
\hline & 0.8 & $2 \cdot 7$ & $7 \cdot 2$ & 12.5 \\
\hline & 0.7 & $2 \cdot 6$ & 6.6 & 12.6 \\
\hline & 0.6 & $2 \cdot 6$ & $7 \cdot 0$ & $11 \cdot 0$ \\
\hline & 0.5 & 2.8 & $6 \cdot 2$ & $12 \cdot 3$ \\
\hline & 0.7 & $2 \cdot 7$ & $6 \cdot 8$ & 12.0 \\
\hline & 0.5 & 2.7 & $6 \cdot 7$ & 11.8 \\
\hline & 0.5 & $2 \cdot 6$ & $6 \cdot 6$ & 11.8 \\
\hline & 0.7 & $2 \cdot 7$ & $6 \cdot 8$ & 10.8 \\
\hline & 0.7 & $2 \cdot 6$ & $6 \cdot 8$ & $12 \cdot 3$ \\
\hline & 0.6 & $2 \cdot 6$ & $6 \cdot 7$ & 12.5 \\
\hline & 1.0 & $2 \cdot 6$ & $7 \cdot 0$ & 12.6 \\
\hline & 0.5 & 2.5 & 5.9 & 11.5 \\
\hline & 0.9 & 2.5 & $6 \cdot 8$ & 12.0 \\
\hline & 0.7 & 2.6 & $6 \cdot 8$ & $11 \cdot 3$ \\
\hline & 0.7 & $2 \cdot 6$ & $7 \cdot 0$ & $12 \cdot 1$ \\
\hline & 0.6 & $2 \cdot 8$ & $6 \cdot 8$ & $13 \cdot 5$ \\
\hline & 0.5 & $2 \cdot 7$ & $6 \cdot 6$ & $12 \cdot 1$ \\
\hline & 0.7 & $2 \cdot 6$ & $7 \cdot 0$ & $11 \cdot 7$ \\
\hline Mean & 0.7 & $2 \cdot 6$ & $6 \cdot 7$ & 12.0 \\
\hline SD & 0.2 & $0 \cdot 1$ & $0 \cdot 3$ & 0.7 \\
\hline CV \% & $28 \cdot \overline{6}$ & 3.8 & $4 \cdot 5$ & 5.8 \\
\hline
\end{tabular}

ANTIBIOTIC THERAPY

The microbiological assays of six sera were very low and less than a quarter of their radioisotope result. All six patients were receiving antibiotics ( 3 cotrimoxazole, 1 ampicillin, 1 rifampicin, 1 crystamycin). Twelve other patients receiving antibiotics did not show such discrepancy.

WHOLE BLOOD FOLATE ASSAYS

Fifty-five haemolysates from hospital patients were

Table 5 Effect of dilution on high folate sera

\begin{tabular}{llrl}
\hline Serum & \multicolumn{2}{l}{ Final serum dilution } \\
\cline { 2 - 4 } & $1 / 21$ & $1 / 42$ & $1 / 84$ \\
\hline 1 & 11.2 & 5.0 & $2 \cdot 5$ \\
2 & 12.0 & 6.0 & 3.0 \\
3 & 15.2 & 7.6 & 3.9 \\
4 & 20.0 & 10.5 & 5.3 \\
5 & $20.0+$ & 4.2 & 2.7 \\
6 & $20.0+$ & 9.0 & 4.5 \\
7 & $20.0+$ & 11.5 & 5.6 \\
Mean & $16.9+$ & 7.7 & 3.9 \\
\hline
\end{tabular}

Table 6 Comparison of costs

\begin{tabular}{lcc}
\hline & L. casei & 'Quanta Count' \\
\hline Salaries & $£ 15 \cdot 54$ & $£ 8 \cdot 88$ \\
Media & $£ 9.20$ & - \\
Electricity, etc. & $£ 5.40$ & $£ 3.60$ \\
Counting vials & - & $£ 8.96$ \\
'Quanta Count' kit & - & $£ 136.00$ \\
$(200 \times 2$ test $)$ & - & $78.7 p$ \\
Cost per duplicate test & \multicolumn{1}{c}{$15 \mathrm{p}$} & \\
\hline
\end{tabular}

tested by both techniques. The relationship is shown in Figure 2.

$\cos \mathrm{T}$

The breakdown of the costs of folate assays carried out in the laboratory by both techniques is shown in Table 6 . These are based on testing 200 samples in duplicate.

Table 4 Recovery of added Pte-Glu

\begin{tabular}{|c|c|c|c|c|c|}
\hline Serum & Untreated & Plus $5 \mu \mathrm{g} / \mathrm{l}$ & Recovery (\%) & Plus $10 \mu \mathrm{g} / \mathrm{l}$ & Recovery (\%) \\
\hline $\begin{array}{l}1 \\
2 \\
3 \\
4 \\
5 \\
6 \\
7 \\
8\end{array}$ & $\begin{array}{l}2 \cdot 5 \\
5 \cdot 9 \\
1 \cdot 4 \\
1 \cdot 4 \\
4 \cdot 0 \\
1 \cdot 0 \\
2 \cdot 1 \\
2 \cdot 1\end{array}$ & $\begin{array}{l}6 \cdot 5 \\
9 \cdot 8 \\
5 \cdot 6 \\
5 \cdot 7 \\
7 \cdot 8 \\
5 \cdot 3 \\
7 \cdot 0 \\
6 \cdot 6\end{array}$ & $\begin{array}{l}80 \\
78 \\
84 \\
86 \\
76 \\
86 \\
98 \\
90\end{array}$ & $\begin{array}{r}11.0 \\
13.0 \\
10.0 \\
10.5 \\
11.8 \\
9.4 \\
11.6 \\
10.9\end{array}$ & $\begin{array}{l}85 \\
71 \\
86 \\
91 \\
78 \\
84 \\
95 \\
88\end{array}$ \\
\hline $\begin{array}{l}\text { Mean } \\
\text { SD } \\
\text { CV \% }\end{array}$ & $2 \cdot 6$ & $6 \cdot 8$ & $\begin{array}{r}84 \cdot 8 \\
7 \cdot 1 \\
8 \cdot 4\end{array}$ & $11 \cdot 0$ & $\begin{array}{r}84 \cdot 8 \\
7 \cdot 5 \\
8 \cdot 8\end{array}$ \\
\hline
\end{tabular}




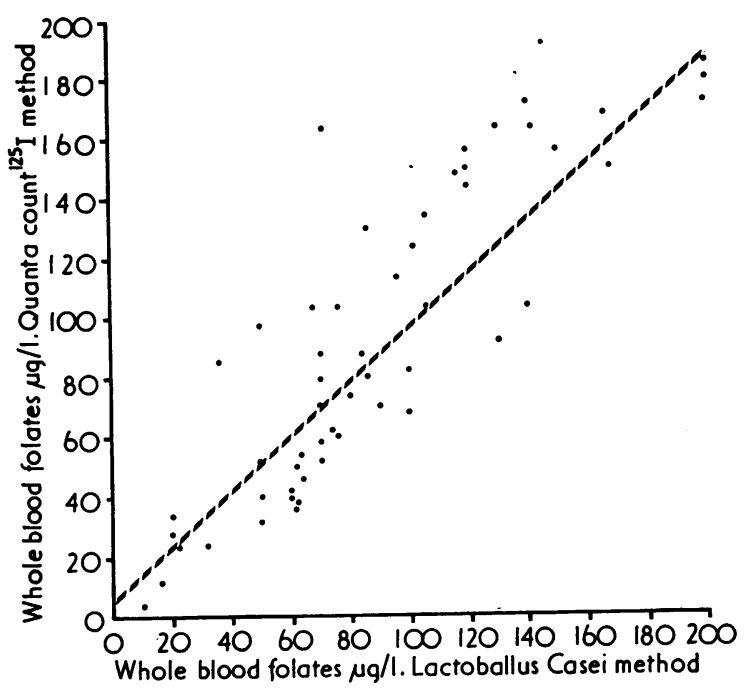

Fig. 2 Comparison of whole blood folate values obtained for 55 haemolysates by the 'Quanta Count' and Lactobacillus casei methods Regression line, $x=0.95 y-7 \cdot 16$.

\section{Discussion}

The radioisotope kit which we have tried has been found easy and reliable to use and capable of giving precise results after a minor technical modification. Although we did not relate the assays to clinical data we found a close correlation between the results with it and with our microbiological system. The in-batch reproducibility (Table 3 ) was, with normal sera, comparable with our own and with published microbiological techniques (Waters and Mollin, 1961; Millbank et al., 1970). Although the subnormal sera yielded much greater in-batch variability all results were of the same order. Kits of different batch number used at the same time and the same kit used at the beginning and end of its shelf-life gave satisfactory results. Testing sera in a microbiological system at higher dilutions may yield higher results (Millbank et al., 1970) but this was not observed with the isotope system.

The radioisotope results were usually lower than the microbiological assays and the recovery of added folic acid was less than ideal. These differences should not have been due to folate binders in the test serum, a cause of low results in some radioisotope tests (Rothenberg and da Costa, 1974), because the serum was heated to inactivate the binders. However, this step was carried out without the protective effect of ascorbic acid, except in the experiment concerning shelf-life (Table 1) when, interestingly, the results before storage were similar in the two assays. Ascorbic acid causes an apparent increase in serum folate in a tritium radioassay technique (Lindemans et al., 1975) and may have produced this result. Dunn and Foster (1973) found that an alkaline pH preserves folate during heat denaturation in the absence of ascorbic acid. The slight difference in binding affinities of lactoglobulin for methylfolate (serum) and folic acid (standards) at the $\mathrm{pH}$ of 9.6 of the isotope system is biased toward yielding an apparently higher serum folate (Givas and Gutcho, 1975).

The other advantages of the kit are the speed with which results may be obtained and the lack of inhibition by antibiotics. A batch of 200 tests can be carried out in one day by one technician. But against these factors must be set the high cost per test. Our figures are based on the use of a kit for testing 200 samples. The use of the smaller kit would increase the cost per sample, The several other commercial kits now available are not dissimilar in price. The low inbatch variability indicates that it would be reasonable to test each samplesingly, therebyalmost halving the cost, and the unused part of a kit may be stored. There are few published data on the expense of routine microbiological assays, but that from Edinburgh (Hayward and Ford, 1974) shows that elsewhere the cost may be much higher than ours. A laboratory which does not have a satisfactory microbiological system in use and has to do batches of up to 20 tests may consider the radioisotope kit price a reasonable one.

The erythrocyte polyglutamates are first incubated with serum conjugase to split them to triglutamates and monoglutamates before microbiological assay. Radioassay may not be sensitive to both, and incomplete deconjugation may explain the difference in regression lines between serum and whole blood folates.

We are grateful to Bio-Rad Laboratories for the supply of kits used in this evaluation.

\section{References}

Dunn, R. T. and Foster, L. B. (1973). Radioassay of serum folate. Clinical Chemistry, 19, 1101-1105.

Givas, K. K. and Gutcho, S. (1975). pH dependence of $\square$ the binding of folates to milk binder in radioassay of $\bar{O}$ folates. Clinical Chemistry, 21, 427-428.

Hayward, M. J. and Ford, A. (1974). Serum $B_{12}$ and folic $\frac{\rho}{\mathbb{D}}$ acid assays - a critical view. Health Bulletin, 32, 63-65. @

Hoffbrand, A. V., Newcombe, B. F. A., and Mollin, D. ํ L. (1966). Method of assay of red cell folate activity and $\Omega$ the value of the assay as a test for folate deficiency. 
Journal of Clinical Pathology, 19, 17-28.

Lindemans, J., van Kapel, J., and Abels, J. (1975). Evaluation of a radioassay for serum folate and the effects of ascorbate and methotrexate. Clinica Chimica Acta, 65, 15-20.

Millbank, L., Davis, R. E., Rawlins, M., and Waters, A. H. (1970). Automation of the assay of folate in serum and whole blood. Journal of Clinical Pathology, 23, 5459.

Rothenberg, S. P. and da Costa, M. (1974). Letter. Blood, 43, 310-312.

Waters, A. H. and Mollin, D. L. (1961). Studies on the folic acid activity of human serum. Journal of Clinical Pathology, 14, 335-344.

\section{The April 1977 Issue}

\section{THE April 1977 ISSUE CONTAINS THE FOLLOWING PAPERS}

Characterisation of immunofluorescent heterophile antibodies which may be confused with autoantibodies B. R. HAWKINS, B. L. MCDONALD, AND R. L. DAWKINS

Circulating immune complexes in subacute infective endocarditis and post-streptococcal glomerulonephritis IDRIS MOHAMMED, BARBARA M. ANSELL, E. J. HOLBOROW, AND A. D. M. BRYCESON

Halothane macrophage migration inhibition factor test in halothane-associated hepatitis C. D. PRICE, A. R. GIBBS, AND W. JONES WILLIAMS

Pathology of 'non-healing (midline) granuloma' $\quad$ L. MICHAELS AND MONICA M. GREGORY

Hypophosphataemic osteomalacia associated with a malignant tumour of the tibia: report of a case A. $\mathbf{L}$. WYMAN, F. J. PARADINAS, AND J. R. DALY

Centrifugation techniques and reagent strips in the assessment of microhaematuria S. C. FRENI, G. J. HEEDERIK, AND C. HOL

Erythrocyturia, smoking, and occupation s. C. FRENI, L. M. DALDERUP, J. J. OUDEGEEST, AND N. WENSVEEN

A comparison of the erythrocyte sedimentation rate and plasma viscosity in detecting changes in plasma proteins R. M. HUTCHINSON AND R. D. EASTHAM

Effect of local exercise and vessel occlusion on fibrinolytic activity J. A. N. RENNIE, B. BENNETT, AND D. OGSTON
Automated red cell indices and marrow iron reserves in geriatric patients C. G. L. RAPER, C. ROSEN, AND M. CHOUDHURY

Maintenance and use of cumulative haematology files on a laboratory computer M. K. ALEXANDER, M. T. CORBETT, AND R. W. REED

Evaluation of a semi-automated platelet-counting system R. M. ROWAN, C. FRASER, J. H. GRAY, AND G. A. MCDONALD

Platelet dynamics in chronic liver disease with special reference to the role of the spleen P. J. TOGHILL, SHEILA GREEN, AND ROGER FERGUSON

A regional quality control trial of folate assays D. W. DAWSON AND D. A. NEWSOME

Aminoglycoside-resistant enterococci M. J. BASKER, B. SLOCOMBE, ANL R. SUTHERLAND

Test reproducibility of the API (20E), Enterotube, and Pathotec systems B. HOLMES, W. R. WILlCOX, S. P. LAPAGE, AND H. MALNICK

Detection of Aspergillus fumigatus precipitins: a comparison of counter immunoelectrophoresis and double diffusion D. W. WARNOCK

\section{Technical method}

The Micro-Compu-Pet: a multi-channel diluter and dispenser B. MELLARS

Letter to the Editor

Book reviews

Copies are still available and may be obtained from the PUBLISHING MANAGER, BRITISH MEDICAL ASSOCIATION, TAVISTOCK SQUARE, LONDON WC1H 9JR, price $£ 3.00$, including postage 